\title{
Upaya Meningkatkan Hasil Belajar Pendidikan PKn melalui Pembelajaran Learning Community pada Siswa Sekolah Dasar
}

\author{
Kamaluddin ${ }^{1}$, Aenul Hidayat ${ }^{2}$
}

\author{
${ }^{1}$ Pendidikan Pancasila dan Kewarganegaraan, Universitas Muhammadiyah Mataram, kamaluddin@gmail.com \\ ${ }^{2}$ Pendidikan Pancasila dan Kewarganegaraan, Universitas Muhammadiyah Mataram, aenul.hidayat23@gmail.com
}

\begin{abstract}
INFO ARTIKEL
Riwayat Artikel:

Diterima: 15 September

2020

Disetujui: 30 September 2020
\end{abstract}

Kata Kunci:
Meningkatkan
Hasil belajar
PKn
Pembelajaran
Lerning community

\section{A. LATAR BELAKANG}

Permasalahan pendidikan di Indonesia terletak pada rendahnya mutu pendidikan dasar pada setiap jenjang baik jenjang dasar, menengah maupun jenjang atas. Pendidikan Pancasila dan Kewarganegaraan (PPKn) adalah salah satu mata pelajaran yang diberikan mulai dari jenjang sekolah dasar (SD/MI) sampai sekolah menengah (SMA/MA/SMK), dan di dalam kurikulum sekolah pendidikan pancasila dan kewarganegaraan berfungsi membangun kemampuan dan membentuk watak serta peradaban bangsa yang bermartabat dalam rangka mencerdaskan bangsa, bertujuan untuk berkembangnya potensi peserta didik agar menjadi manusia yang beriman dan bertakwa kepada Tuhan Yang Maha Esa, berahlak, nilai, sehat, berilmu, cakap, kreatif, mandiri dan menjadi warga Negara yang demokratis serta tanggung jawab. Namun kenyataan yang terjadi ada beberapa hasil belajar siswa sekolah tidak mencapai standard kelulusan.

Hasil penelitian sebelumnya menunjukkan bahwa pembelajaran learning community dapat meningkatkan kempotensi guru sehingga berdampak meningkatnya hasil belajar siswa,[1] pengembangan model ADDIE dikolaborasikan dengan learning community dapat mengembangkan inovasi siswa.[2] Penerapan teknik Learning Community dapat meningkatakan aktivitas dan hasil belajar siswa dan aktivitas siswa setelah diterapkan oleh guru kelas.[3] Dampak penerapan model pembelajaran Learning Community tema lingkungan pada pembelajaran tematik dapat meningkatkan aktivitas, rasa senang dan kreativitas siswa dalam proses pembelajaran.[4] Tingkat keaktifan siswa pada mata pelajaran IPS dengan strategi Learning Community telah mampu meningkatkan keaktifan belajar siswa, baik bertanya, memecahkan masalah, dan megerjakan tes.[5] Pembelajaran learning community 
bagi guru, teman sejawat, kepala sekolah dan praktisi dapat memberikan dampak yang signifikan.[6]

Beberapa penelitian tersebut melakukan kajian pada aspek mengukur aktivitas belajar, rasa senang siswa, kreativitas siswa, penerapa pembelajaran learning community, dampak yang signifikan pada siswa sekolah terutama aspek pengetahuannya. Sementara aspek pada pelajaran pendidikan pancasila dan kewarganegaraan belum diuraikan secara detail. Kajian pembelajaran learning community sangat perlu dikembangkan lagi lebih dalam untuk menghasilkan temuan baru, perbaikan teori pembelajaran maupun dampak lainnya untuk pengembangan keilmuan metode pembelajaran. Learning community.

Berdasarkan hasil observasi ditemukan faktor atau kendala yang menyebabkan hasil belajar PPKn belum optimal antara lain: (1) Guru lebih banyak menggunakan metode ceramah, sehingga siswa menjadi cepat bosen disebakan karena guru kurang menguasai metodemetode pembelajaran ; (2) minat dan motivasi siswa dalam mengikuti pelajaran sangat rendah di sebabkan penggunaan metode yang monoton oleh guru; (3) terbentuknya kelompok belajar yang masih bersifat individu disebabkan kurang alternatif guru dalam menggunakan belajar kelompok dalam pembelajaran; (4) siswa masih belum terbiasa untuk saling bertukar pendapat disebkan tidak terbiasa; (5) Hasil belajar PPKn belum optimal yakni belum mencapai angka minimal standar ketuntasan yakni nilai 70 keatas yang sudah ditentukan dalam K13. Hasil Ujian Mid Semester I mata pelajaran PPKn Siswa persentase ketuntasan klasikal 43,24\%. Jadi kelas tersebut belum dikatakn tuntas secara klasikal, karena dalam uraikan permen diknas suatu kelas dikatakan tuntas belajarnya jika dikelas tersebut telah mencapai ketuntasan klasikal $\geq 85 \%$.[7]

Dengan demikian hendaknya guru berupaya untuk membuat siswa dalam memahami pelajaran, khususnya pembelajaran PPKn. Guru dituntut untuk memilih metode yang tepat agar tujuan pembelajaran yang telah disusun, dapat tecapai dengan maksimal. Salah satu alternatif metode yang dapat dikembangkan untuk memenuhi tuntuna tesebut adalah melalui learning community. Metode Learning community merupakan hasil pembelajaran yang diperoleh dari kerjasama dengan orang lain. Hasil belajar diperoleh dari sharing antar teman, antar kelompok, dan atar siswa yang tau dengan siswa yang belum tahu, sehingga terbentuk komunukasi multi arah[8]. Langkah-langkah pembelajaran ini memberikan kesempatam kepada siswa dengan berbagai latar belakang dan kondisi sosial yang berbeda untuk kerjasama saling berbagi informasi dan mengungkapkan pendapat dan belajar saling mengargai satu dengan yang lainnya dan memecahkan yang diberikan oleh guru.

Learning communities can be effective, and offer a feasible solution for different issues and diverse institutional realities.[9] Learning community merupakan reformasi sekolah untuk mengefektifkan pembelajaran uantuk mengetahuai letak kelemahan dan kelebihan seorang guru, untuk saling memberikan masukan untuk perbaikan pengajaran.[10] learning community merupakan pembelajaran efektif, sangat fleksibel untuk mengungkapkan berbagai masalah untuk didiskusikan dalam kelas, serta pembelajaran sejawat untuk memberikan saran kritik dalam proses pembelajaran yang dilakukan oleh siswa.

Pendidikan Pancasila dan kewarganegaraan pada hakekatnya adalah pendidikan untuk menjadi, artinya bagaimana mendidik manusia menjadi manusia yang manusiawi, yang pada dasarnya untuk mengembangkan potensi moral sebagai kebutuhan dasar bagi mewujudkan kehidupan yang aman, damai, dan tenteram pada umat manusia. Dalam era kekinian, mata pelajaran PPKn dalam kontek pendidikan karakter dapat dimaknai sebagi pendidikan nilai, pendidikan budi pekerti, pendidikan moral, pendidikan watak untuk mengembangkan kemampuan peserta didik. Sehingga pendidikan kararakter dapat di maknai sebagai suatu sistem penanaman nilai karakter kepada warga sekolah yang meliputi komponen pengetahuan, kesadaran atau kemauan, dan tindakan untuk melaksanakan nilai-nilai tersebuat baik terhadap Tuahn Yang MahaEsa, diri sendiri, sesama, lingkuangan, maupun bangsa dan Negara.[11]

Dalam Materi Kerja Guru, dalam undang-undang no. 2 tahun 1989 tentang sistem Pendidikan Nasional penjelasanya Pasal 39 ayat 2[12] menjelaskan arah mata pelajaran PPKn dilatar belakangi perhatian pada moral yang diharapkan diwujudkan kehidupan sehari-hari yaitu perilaku yang memancarkan iman dan taqwa terhadap Tuahan Yang Maha Esa dalam masyarakat yang terdiri atas berbagai golongan prilaku yang bersifat kemanusiaan yang adil dan beradab, prilaku yang mendukung persatuan bangsa dalam masyrakat yang beraneka rangam kebudayaan dan beranekaragam kepentingan, perilaku yang mendukung kerakyatan yang mengutamakan kepentingan bersama diatas kepentingan perorangan dan golongan sehingga perbedaan pemikiran, pendapat ataupun kepentingan diatasi melalui musyawarah dan mufakat serta prilaku yang mendukung upaya yang mendukung upaya yang mewuudkan keadilan social bagi seluruh rakyat Indonesia.

Kelemahan berbagai penelitian sebelumnya terletak pada subyek penelitian masih sedikit, pendekatan yang digunakan hanya qualitative, penerapa pada sekolah dasar belum maksimal. Dengan demikian, artikel ini akan memberikan warna baru berdasarkan hasil penelitiannya yang dilakukan pada sekolah dasar pada mata pelajaran pendidikan pancasila dan kewarganegaraan di kota Mataram. Dalam artikel ini berupaya menjelaskan upaya meningkatkan hasil belajar 
melalui leraning community pada pendidikan pancasila dan kewarganegaraan untuk siswa sekolah dasar, mengukur efektifnya pembelajaran learning community dan determinasi variable leraning community dan hasil belajar siswa. Tujuan dalam artikel ini untuk mengtahui upaya meningkatkan hasil belajar pendidikan PKn melalui pembelajaran learning community pada siswa sekolah dasar.

\section{B. METODE PENELITIAN}

\section{Prosedur penelitian}

Prosedur penelitian merupakan langkah-langkah oprasional baik yang berkaitan dengan perencanaan, pelaksanaan, obsevasi/ evaluasi, maupun refleksi. Preosedur penelitian yang digunakan dalam penelitian ini menggunakan konsep penelitian tindakan kelas. Penelitian tindakan kelas (PTK) ini sangat bermamfaat bagi guru untuk meningkatkan mutu proses dan hasil pembelajran di kelas. Dengan melaksanakan tahaptahap PTK, guru dapat menemukan solusi dari masalahmasalah yang timbul dikelas sendiri, dengan menerapkan berbagai macam teori dan tehnik pembelajaran serta mengefektifkan penggunaan metode pemberian tugas dalam menyampaikan materi pelajaran yang relevan secara kreatif.

Dalam penelitian ini menggunakan langkah-langkah sebagai berikut:

\section{a. Perencanaan}

Perencanaan yang dilakukan pada siklus I yaitu, membuat perangkat pembelajaran berupa, a) menyusun silabus pembelajaran, b) membuat rancanagan pelaksanaan pembelajaraan siklus, c) menyusun kisi-kisi soal evaluasi siklus, d) menyusun instrument soal evaluasi siklus, e) menyusun pedoman lembar observasi guru dan siswa siklus.

\section{b. Pelaksanaan Tindakan}

Tahap pelaksanaan tindakan ini, guru dan peneliti menerapkan pembelajaran di kelas yakni dengan menggunakan metode Learning Community sesuai dengan langkah-langkah pembelajaran yang ada dalam dan rencana pelaksanaan pembelajaran (RPP) yang telah disusun, yaitu terdiri asat kegiatan awal (pendahuluan), kegiatan inti, dan kegiatan akhir (Penutup).

\section{c. Observasi dan Evaluasi}

Tahap-tahap ini dilakukan pemantauan untuk mengetahui yaitu, 1) apakah proses pembelajaran telah mencerminkan penggunaan pembelajarn yang berorentasi pada learning community secara optimal. 2) apakah seluruh isi rancangan pembelajaran telah diperaktikan secara optimal dalam proses pembelajaran. 3) adakah kesalahan-kesalahan yang dilakukan oleh guru dalam mepraktekan seluruh komponen pembelajaran. 4) mengetahui danpak pembelajran yang berorentasi pada learning community terhadap peningkatan hasil belajar siswa selam proses pembelajaran. 5) memantau danpak pembelajaran yang berorientasi pada learning community terhadap tingkat pemahaman materi setelah selesai satu rencana pembelajaran.

Kegiatan obsevasi dilakukan setiap pembelajaran berlangsung. Pelaksanaan tindakan dengan mengamati aktivitas siswa dan aktivitas guru. Dalam obsevasi pengamatan instrumen lembar observasi dengan cara memberikan tanda ceklis $(\sqrt{ })$ pada kolom yang sesuai denagn kemunculan Indikator yang diamati. Evaluasi dilakukan denaga memberikan tes tulis dalam bentuk tes obyektif dengan 4 pilihan. Jumlah soal evaluasi 15 butir, dengan bobot 1 setiap soal, denag skor maksimal 15 .

d. Refleksi

Tahap refleksi, peneliti akan melakukan perenungan apakah metode learning community sudah mampu meningkatkan hasil belajar siswa. Tahap refleksi dilakukan setelah mengumpulkan semua data yang diperoleh dalam tahap peaksanaan tindakan dan observasi.

Tindakan yang diproses pada siklus pertama akan dievaluasi dan dan akan dijadika bahan pertimbangan untuk melakukan tindakan berikutnya. Hal ini dilakukan untuk mengetahui apakah pelaksanaan metode learning community dapat meningkatkan hasil belajar sesuai denag siklus pertama. Selain itu pada tahap refleksi ini, guru akan merefleksi diri dengan melihat data observasi yang dilakukan, yakni apakah sesuai dengan rencana sebelunya atau tidak. Dengan demikian akan diketahui letak kelemahan dari hasil tindakan untuk melakukan perbaikan pada siklus berikutnya jika di perlukan.

\section{HASIL DAN PEMBAHASAN}

\section{Deskripsi Data Siklus I}

Siklus I ini dilaksanakan dua kali pertemuan dengan alokasi waktu $3 \times 35$ menit (105 menit) dengan tahapan pelaksanaannya yaitu:

a. Tahap Perencanaan Tindakan.

Dalam perencanan untuk menyusun pengembangan silabus, dalam penyusunan pengembangan silabus, pelaksanaan yang dilakukan dalam penyusunan silabus yaitu menentukan secara umum proses pembelajaran yang akan dilaksanakan dengan kopetensi inti dan kopetensi dasar terlebih dahulu. Setelah itu menentukan materi pokok yang diajarkan, didalam penyusunan pengembangan silabus juga dijelaskan menjelsakan tentang Indikator materi yang diajarkan yaitu sistem pemerintahan desa. Setelah menentukan indikator maka akan di perjelas dengan kegiatan pembelajaran disertai denagn proses dan alokasi waktu, penilaian dan sumber belajar.

Pertama, Membuat Rencana Pelaksanaan Pembelajaran. Dalam membuat rencana pelaksanaan siklus I ilakukan perencanaan bagaimana proses pembelajaran akan berlangsung ini sesuai dengan langkah-langkah dalam penulisan RPP. Dimana dalam RPP ini dijelaskan mulai dari kopetensi inti, kopetensi dasar, Indikator, tujuan pembelajaran, materi pembelajaran, metode pembelajaran, media dan alat- 
alat pembelajaran, langkah-langkah pembelajaran serta evaluasi atau tehnik penilaian. Dalam pembuatan RPP ini juga dilengkapi dengan pembuatan Lembar Kerja Siswa (lampiran 4) tentang sistem pemerintahan desa. Petunjuk LKS menyebutkan struktur pemerintahan desa.

Kedua, Menyusun kisi-kisi soal evaluasi. Menyusun kisi-kisi soal evaluasi siklus I sesuai dengan materi yang diajarkan ke siswa dan dalam menyusun kisi-kisi soal ini sesuai dengan Indikator. Pada Indikator pertama yakni menjelaskan sistem pemerintahan desa dengan nomor soal yang diambil yaitu 2, 4,6,11,16,17,19,. Indikator kedua menjelaskan pemerintahan kelurahan \dengan nomor soal yang di ambil 1,3,5,8,14,15,19. Indikator ketiga menggambarkan struktur organisasi desa dan kelurahan dengan nomor soal 7,9,10,12,13,18.

Ketiga, Menyusun instrument soal. Menyusun insrtumen soal siklus I ini yang mengacu pada materi yang dipelajari yaitu tentang sistem pemerintahan desa dimana sulit kesukaran soal disesuaikan dengan kemampuan siswa . jumlah instrument soal pada siklus I ini sebanyak 20 butir dengan pilihan ganda . instrument soal ini di lengkapi dengan lembar jawaban dengan member tanda silang pada hurup A, B, C, dan D pada lembar jawaban yang sudah ada.

Keempat, Membuat kunci jawaban dan penskoran soal evaluasi. Membuat kunci jawaban pada siklus ini disesuaikan berdasarkan instrument soal yang sudah ada, penskoran soal evaluasi yakni setiap soal bobotnya 5 dan skor maksimalnya adalah 100. Prolehan nilai siswa di hiting dengan rumus: $\mathrm{N}=\mathrm{T} /\left(\mathrm{t}_{\mathrm{t}}\right) \times 100$

Dengan keterangan $\mathrm{N}=$ ketuntasan belajar persiswa.

$\mathrm{T}=$ skor yang dicapai siswa, $\mathrm{t}_{\mathrm{t}}=$ jumlah siswa yang ikut tes.

\section{b. Tahap pelaksanaan tindakan}

Kegiatan awal berupa apersepsi, memberikan informasi tentang pentingnya materi yang dipelajari, menyediakan alat bahan, dan sumber belajar, guru menyampaikan tujuan pembelajaran. Kegiatan inti berupa guru menyampaikan informasi tentang materi yang akan dipelajari, menunjukan gambar tentang sistem pemerintahan desa, Siswa dibagi menjadi beberapa kelompok yang heterogen, masing-masing kelompok terdiri dari 6-7 orang, guru membimbing siswa dalam melaksanakan learning community (belajr kelompok), guru membagi LKS kepada masing-masing kelompok untuk didiskusikan secara bersama-sama dengan anggota kelompoklainya, guru membimbing dan memberikan pengarahan kepada siswa ketika siswa mengerjakan LKS, memberikan kepada masing-masing kelompok untuk mempersentasikan hasil kelompoknya, memberikan kesempatan kepada kelopok lain untuk memberikan masukan dan tanggapan sehingga dapat menemukan pemecahan masalah dari materi yang dibahas, guru memberikan penguatan tentang penilaian tentang hasil kerja masing-masing kelompok, guru memberikan penghargaan kepada kelompok yang kerja kelompoknya paling aktip dan kompak serta memberikan motivasi bagi kelompok yang hasil kelopoknya kurang maksimal serta mengadakan evaluasi.

\section{c. Kegiatan penutup}

Kegiatan ini berupa membuat kesimpulan materi pembelajaran yang sudah di bahas, memberikan tugas rumah yaitu merangkum materi tentang sitem pemerintahan desa.

Tujuan mempelajari siklus I adalah dengan media gambar, siswa dapat menjelaskan sistem pemerintahan desa, pemerintahan kelurahan dan membuat struktur organisasi pemerintah desa dan pemerintah kelurahan.Pada saat pembelajaran berlangsung ada beberapa siswa yang kuarang fokus dalam mengikuti pembelajaran, siswa terlihat masih bingung dan kurang antusia dalam memperhatikan guru ketika menjelaskan materi pembelajaran dengan mengunakan metode learning community (belajar kelompok) dapat meningkatkan keaktifan siswa dalam menyelesaikan masalah yang berkaitan dengan materi yang di ajarkan.

\section{d. Hasil Tindakan}

Setelah dianalisis tes hasil belajar siswa pada siklus I diproleh data yang diuraikan pada grafik 1.

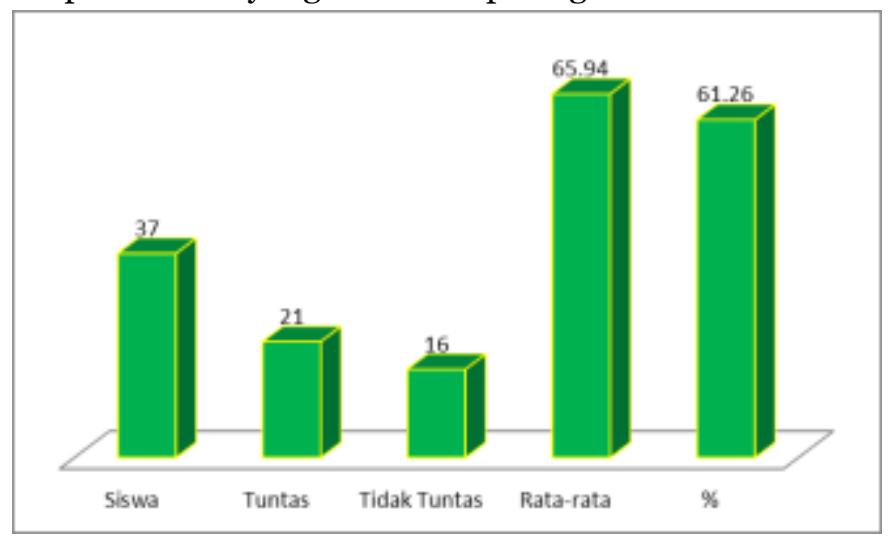

Grafik 1. hasil evaluasi belajar siswa siklus I

Kemudian diolah dengan perhitungan ketuntasan mencapai 56.76\%. Perolehan hasil tersebut menunjukan bahwa hasil belajar siswa belum tercapai karena ketuntasan belajar masih kurang dari $85 \%$.

\section{e. Refleksi}

Berasarkan hasil tes belajar siswa menunjukan hasil yang dicapai dengan ketuntasan klasikal $56.76 \%$ berarti belum memenuhi Indikator keberhasilan ketuntasan belajar sekurang-kurangnya $85 \%$. Oleh karena itu perlu dilakukan upaya perbaikan perencanaan tindakan untuk melaksanakan kegiatan pembelajaran pada siklus II. Perbaikan-perbaikan yang dilakukan antara lain:

1) Kesiapan siswa untuk belajar masih kurang ini terlihat dari beberapa siswa yang tidak membawa alat tulis bahkan buku paket . untuk itu guru mengingatkan pada siswa agar menyiapkan yang diperlukan dan membawa buku paket pada pembelajaran berikutnya. 
2) Komunikasi dan kerja sama dalam kelompok kurang. Siswa Yang berkemampuan rendah maupun berkemampuan tinggi kurang mau bekerja sama. Untuk mengatasi hal tersebut maka pada sikus II guru lebih menjelaskan an menekankan lagi pengguna an metode learning community dan guru juga menemukan tutor sebaya pada tiap kelompok agar mau memberikan penjelasan pada temanya yang belum biasa. Guru memberikan pengarahan kepada siswa bahwa kelompok yang berhasil apabila setiap anggota kelompok mengerti atau menjawab pertanyaan yang diberikan dan terjalin kerjasama yang baik diantara anggota kelompok.

3) Ketika siswa diberikan untuk diskusi kelompok, beberapa siswa mengalami kesulitan dan memerlukan waktu yang cukup banyak untuk menentukan jawaban. Melihat kendala ini, maka pada siklus II guru menjelaskan tentang pentingnya pembagian tugas dalam kelompok agar semua anggota kelompok mempunyai tanggung jawab. Isamping itu guru memberikan bimbingan secara merata baik perorangan maupun kelompok.

4) Pada saat siswa mempersentasikan hasil diskusi kelompok, masih di dominasi oleh satu orang siswa yang berani berbicara, sedangkan yang lain hanya mendenagrkan dan diam. Utntuk mengatasi masalah tersebut guru menekankan bahwa setiap kelompok yang maju harus semua kelompoknya berani mengemukakan pendapat hasil diskusi mereka.

5) Pada saat siswa melakukan persentase, teman sesame teman kelompoknya membantu untuk menjawab soal-soal yang sudah disediakan. Pada diskusi ini masih dominan oleh siswa yang berkemampuan tinggi untuk menjawab, sedangkan siswa yang berkemampuan rendah hanya menonton dan masih men mengandalkan temanya yang berkemampuan tinggi.untuk mengatasi maslah tesebut guru menekankan kepada siswa bahwa setiap anggota kelompok maju harus berani mengemukakan jawaban soal-soal yang sudah tessedia dari hasil diskusi..

\section{Deskripsi Siklus II}

Siklus ini dilakanakan satu kali pertemuan dengan alokasi waktu 2. 35 menit (70 menit). Tahapan pelaksana tindakan pada siklus II sebagi berikut.

a. Tahapan Perencana Tindakan

Hal- hal pokok yang dilakukan pada siklus II dalam penelitian ini yaitu:

1) Membuat rencana pelaksanaan pembelajaran

Dalam membuat rencana pembelajaran pada siklus II dilakukan perencanaan bagaimana proses pembelajaran akan berlangsung sesuai dengan dengan langkah-langkah dalam penulisan RPP ini dijelaskan mulai dari Kopetensi inti, kopetensi dasar, Indikator , tujuan pembelajaran, metode pembelajaran, media, alat dan sumber belajar, langkah-langkah kegiatan pembelajaran dan tehnik penilaian atau evaluasi. Langkah-langkah pembelajarn pada siklus II ini lebih menekankan pada sistem pemerintahan kecamatan. Dalam pembuatan RPP ini juga dilengkapi dengan pembuatan lembar kerja siswa (lampiran 10) tentang struktur organisasi pemerintahan kecamatan. Petunjuk LKS yakni mengisi bagan-bagan yang kosong pada stuktur organisasi pemerintahan kecamatan yang sudah ada dalam LKS dengan benar.

2) Menyusun kisi-kisi soal evaluasi

Menyusun kisi-kisi soal evaluasi siklus II sesuai dengan materi yang diajarkan kesiswa, dalam menyusun kisi-kisi soal pada siklus II ini disesuaikan dengan Indikator dan setiap Indikator terdapat 10 butir soal. Pada Indikator pertama yakni menjelaskan sistem pemerintahan kecamatan, nomer soal yang diambil yaitu $1,2,3,4,5,6,7,11,12,13$,dan Indikator kedua yaitu menggambarkan struktur organisasi kecamatan nomer soal yang diambil yaitu 8,9,10,14,15,16,17,18,19,20.

3) Menyusun instrument soal evaluasi

Menyusun instrumen siklu II ini mengacu pada materi yang dipelajari yaitu sistem pemerintahan kecamatan dimana sulit kesukaran soal disesuaikan dengan kemampuan siswa. Soal pada siklus II ini sebanyak 20 butir dengan pilihan ganda. Instrument soal dilengkapi dengan lembar jawaban, cara siswa menjawab yaitu dengan member tanda silang pada hurup A,B,C, dan D pada lembar jawaban yang sudah ada.

4) Menyusun kunci jawaban dan penskoran soal evaluasi

Membuat kunci jawaban pada siklus II disesuaikan berdasarkan instrument soal yang sudah ada pada siklus II sama dengan penskoran soal pada siklus I.

\section{b. Tahap pelaksana tindakan}

Langkah-langkah pembelajaran berupa, kegiatan awal terdiri atas a) Tanya jawab tentang pembelajaran yang lalu mengenai sistem pemerintahan desa; b) Memberikan motivasi yakni pendalaman materi tentang sitem pemerintahan kecamatan, c) Menyampaikan tujuan pembelajaran.

Kegiatan inti meliputi:

1) Guru menjelaskan materi pembelajaran tentang sistem pemerintahan kecamatan

2) Guru menunjukan beberapa gambar tentang sitem pemerintahan kecamatan

3) Guru membagai kelompok belajar siswa secara hetrogen, masing-masing kelopok terdiri dari 6-7 orang.

4) Guru membagikan LKS pada masing-masing kelompok

5) Siswa berdiskusi dengan kelompok masing-masing tentang sistem pemerintahan kecamatan 
6) Guru membimbing siswa dalam melaksanakan learning community (belajar kelompok)

7) Guru membimbing dalam mengerjakan LKS

8) Guru memmbimbing siswa/ kelompok secara merata

9) Salah satu dalam perwakilan masing-masing kelompok mempersentasikan hasil diskusi kelompoknya dan kelompok lain memberikan tanggapan.

10) Guru memberikan siswa penguatan dan penilainan tentang hasil kerja kelompok

11) Guru memberikan penghargaan terhadap hasil kerja kelompok yang baik dan memberikan motivasi kepada kelompok yang hasil diskusinya kurang maksimal

12) Mengadakan evaluasi

Kegiatan akhir berupa:

1) Membuat rangkuman dan kesimpulan materi pelajaran yang sudah dibahas yakni guru menyimpulkan materi yaitu sistem pemerintahan kecamatan sedangkan siswa mencatat hal-hal yang dijelaskan oleh guru.

2) Memberikan tugas rumah yang berupa kliping

Tujuan pembelajaran siklus II adalah sama dengan siklus I. yaitu media gambar, siswa dapat mengetahui lembaga-lembaga yang ada dipemerintahan kecamatan, dan menggambarkan stuktur organisasi kecamatan.Pada saat pembelajaran berlangsung ada sebagian kecil siswa yang kurang aktif dalam mengikuti pelajaran, siswa terlihat sudah antusias dan dapat memusatkan perhatianya memperhatikan guru ketika menjelaskan materi pembelajaran.sehingga dapat dinyatakan bahwa dengan menggunakan metode learning community (belajar kelompok) dapat meningkatkan keaktifan siswa dalam menyelesaikan masalah yang berkaitan dengan materi sistem pemerintahan kecamatan.

c. Hasil tindakan

Setelah dianalisis diperoleh data hasil belajar siswa, yang dijabarkan pada grafik 2 .

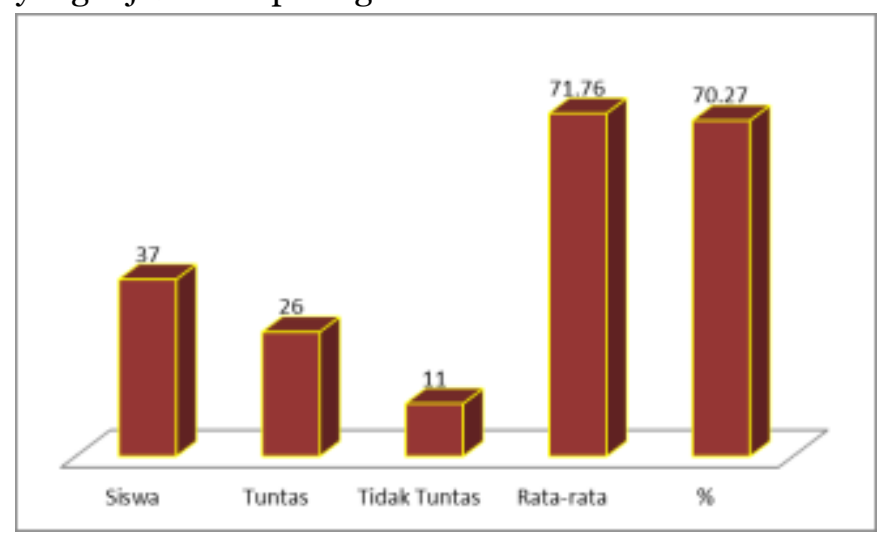

Grafik 2. hasil evaluasi belajar siswa siklus II

Kemudian diolah dengan perhitungan ketuntasan mencapai $70.27 \%$. Persentasi ketuntasan belajar yang diproleh70,27 \% atau dari 37 orang siswa 26 telah tuntas belajar, ketuntasan belajar yang diproleh menunjukan ada peningkatan dari siklus sebelunnya tapi belum memenuhi Indikator keberhasilan, yaitu $85 \%$ (ketuntasan klasikal). Dengan demikian dapat dinyatakan bahwa masih perlu perbaikan-perbaikan pada siklus III.

\section{d. Refleksi}

Dari hasil tes belajar siswa persentase ketuntasan belajar mencapai 70,27\%. Hal ini menunjukan bahwa terjadi peningkatan hasil belajar siswa dari sklus sebelumnya tetapi belum memenuhi indikator keberhasilan, yaitu $85 \%$, karena perencanaan dan pelaksanaan tindakan yang dilakukan dalam penerapan metode learning community yang dilakukan oleh guru blom optimal sengingga pada siklus II siswa merasa malu untuk bertanya, mengajukan pendapat dan menjawab pertanyaan guru, untuk mengatasi masalah tersebut, pada siklus III guru memotivasi siswa untuk lebih berani mengemukakan pendapatnya, tidak takut salah dan dan jika kesulitan maka siswa jangan malu untuk bertanya, baik kepada teman maupun guru.

\section{Deskripsi Siklus III}

Siklus ini dilakanakan satu kali pertemuan dengan alokasi waktu 2. 35 menit (70 menit). Tahapan pelaksana tindakan pada siklus III sebagi berikut.

a. Tahapan Perencana Tindakan

Hal- hal pokok yang dilakukan pada siklus III dalam penelitian ini yaitu:

1. Membuat rencana pelaksanaan pembelajaran

Dalam membuat rencana pembelajaran pada siklus

III dilakukan perencanaan bagaimana proses pembelajaran akan berlangsung sesuai dengan dengan langkah-langkah dalam penulisan RPP ini dijelaskan mulai dari Kopetensi inti, kopetensi dasar, Indikator , tujuan pembelajaran, metode pembelajaran, media, alat dan sumber belajar, langkah-langkah kegiatan pembelajaran dan tehnik penilaian atau evaluasi. Langkah-langkah pembelajarn pada siklus III ini lebih menekankan pada sistem pemerintahan kecamatan. Dalam pembuatan RPP ini juga dilengkapi dengan pembuatan lembar kerja siswa (lampiran 15) tentang struktur organisasi pemerintahan kecamatan. Petunjuk LKS yakni mengisi bagan-bagan yang kosong pada stuktur organisasi pemerintahan kecamatan yang sudah ada dalam LKS dengan benar.

2. Menyusun kisi-kisi soal evaluasi

Menyusun kisi-kisi soal evaluasi siklus III sesuai dengan materi yang diajarkan kesiswa, dalam menyusun kisi-kisi soal pada siklus III ini disesuaikan dengan Indikator dan setiap Indikator terdapat 10 butir soal. Pada Indikator pertama yakni menjelaskan sistem pemerintahan kabupaten/kota, nomer soal yang diambil yaitu 1,2,3,4,5,6,7,8,9,10,dan Indikator kedua yaitu menggambarkan struktur organisasi pemerintahan kabupaten /kota nomer soal yang diambil yaitu $11,12,13,14,15,16,17,18,19,20$.

3. Menyusun instrument soal evaluasi 
Menyusun instrumen siklu III ini mengacu pada materi yang dipelajari yaitu sistem pemerintahan kabupaten/kota dimana sulit kesukaran soal disesuaikan dengan kemampuan siswa. Soal pada siklus III ini sebanyak 20 butir dengan pilihan ganda. Instrument soal dilengkapi dengan lembar jawaban, cara siswa menjawab yaitu dengan member tanda silang pada hurup A,B,C, dan D pada lembar jawaban yang sudah ada.

4. Menyusun kunci jawaban dan penskoran soal evaluasi

Membuat kunci jawaban pada siklus III disesuaikan berdasarkan instrument soal yang sudah ada pada siklus III sama dengan penskoran soal pada siklus II.

b. Tahap pelaksana tindakan

Kegiatan awal berupa tanya jawab tentang pembelajaran yang lalu mengenai sistem pemerintahan kabupaten/kota, memberikan motivasi yakni pendalaman materi tentang sitem pemerintahan kabupaten/kota, menyampaikan tujuan pembelajara.

Kegiatan inti berupa:

1) Guru menjelaskan materi pembelajaran tentang sistem pemerintahan kabupaten /kota

2) Guru menunjukan beberapa gambar tentang sitem pemerintahan kabupaten/kota

3) Guru membagai kelompok belajar siswa secara hetrogen, masing-masing kelopok terdiri dari 67 orang.

4) Guru membagikan LKS pada masing-masing kelompok

5) Siswa berdiskusi dengan kelompok masingmasing tentang sistem pemerintahan kabupaten/kota

6) Guru membimbing siswa dalam melaksanakan learning community (belajar kelompok)

7) Guru membimbing dalam mengerjakan LKS

8) Guru memmbimbing siswa/ kelompok secara merata

9) Salah satu dalam perwakilan masing-masing kelompok mempersentasikan hasil diskusi kelompoknya dan kelompok lain memberikan tanggapan.

10) Guru memberikan siswa penguatan dan penilainan tentang hasil kerja kelompok

11) Guru memberikan penghargaan terhadap hasil kerja kelompok yang baik dan memberikan motivasi kepada kelompok yang hasil diskusinya kurang maksimal

12) Mengadakan evaluasi

Kegiatan akhir berupa membuat rangkuman dan kesimpulan materi pelajaran yang sudah dibahas yakni guru menyimpulkan materi yaitu sistem pemerintahan kabupaten/kota sedangkan siswa mencatat hal-hal yang dijelaskan oleh guru. Memberikan tugas rumah yang berupa kliping.

Tujuan pembelajaran siklus III adalah sama dengan siklus sebelumnya. yaitu media gambar, siswa dapat mengetahui lembaga-lembaga yang ada dipemerintahan kabupaten/ kota, dan menggambarkan stuktur organisasi kabupaten/kota.Pada saat pembelajaran berlangsung ada sebagian kecil siswa yang kurang aktif dalam mengikuti pelajaran, siswa terlihat sudah antusias dan dapat memusatkan perhatianya memperhatikan guru ketika menjelaskan materi pembelajaran.sehingga dapat dinyatakan bahwa dengan menggunakan metode learning community (belajar kelompok) dapat meningkatkan keaktifan siswa dalam menyelesaikan masalah yang berkaitan dengan materi sistem pemerintahan kabupaten/kota.

\section{c. Hasil tindakan}

Setelah dianalisis diperoleh data hasil belajar siswa, yang dijabarkan pada grafik 2.

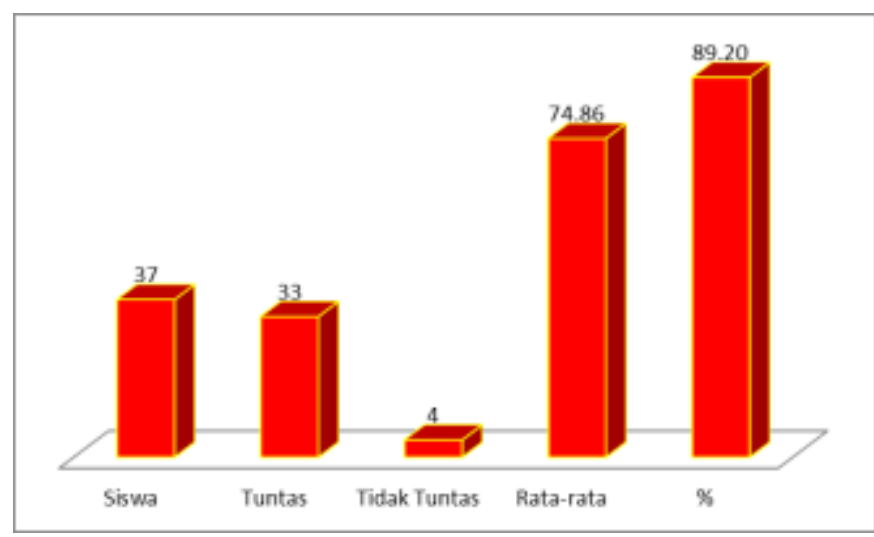

Grafik 3. hasil evaluasi belajar siswa siklus III

Kemudian diolah dengan perhitungan ketuntasan mencapai 89.20\%. Jadi ketuntasan belajar yang diproleh $89,20 \%$ atau dari 37 orang siswa 33 telah tuntas belajar, ketuntasan belajar yang diproleh menunjukan telah melampoi ketuntasan belajar yang telah ditetatpkan dalam Indikator keberhasilan, yaitu $85 \%$. Dengan demikian dapat dinyatakan bahwa hasil belajar siklus III lebih baik dari pada siklus II ataupun sebelumnya.

\section{d. Refleksi}

Dari hasil tes belajar siswa persentase ketuntasan belajar mencapai $89,20 \%$. Hal ini menunjukan bahwa terjadi peningkatan hasil belajar siswa dari sklus sebelumnya, karena perencanaan dan pelaksanaan tindakan yang dilakukan telah dapat menciptakan suasana belajar yang aktif, hanya sebagian kecil yang kurang aktif

\section{TEMUAN ATAU DISKUSI}

Hasil belajar siswa pada siklus I terhadap materi pokok pembelajaran "Sistem Pemerintahan Desa" masih rendah, hal ini terlihat dari rata-rata kelas yang diproleh 69,83 dan ketuntasan belajar 56,76\% atau 21 siswa yang lulus dari 37 orang siswa. Hal ini di sebabkan oleh karena guru belum menerapkan metode learning community (belajar kelompok) secara optimal dan guru belum memberikan bimbingan kepada siswa secara terus menerus serta kurangnya pemberdayaan 
kemampuan awal siswa untuk mengaitkanya dengan materi pelajaran yang dipelajari siswa. Disamping itu kerja sama siswa di kelompok diskusi masih sangat kurang, kemampuan siswa bertanya kepada teman kelompoknya maupun kelompok lain masih masih juga kurang, keberanian siswa mengacuka dalam bertanya, mengemukakan pendapat dan menjawab pertanyaan yang diajukan oleh guru masih minim.

Untuk mengatasi masalah tersebut di atas peneliti melakukan perbaikan-perbaikan dalam proses pembelajaran dan meningkatkan hal-hal yang masih dianggap kurang seperti pemberian motivasi untuk memancing minat siswa mau bertanya tentang masalah yang belum di pahami sehingga siswa bias mengetahui dan dapat menjelaskanya. Dan berdasarkan data tes hasil belajar siswa selama proses pembelajaran dengan menerapkan metode learning community ( belajar kelompok) pada siklus I dalam belum kriteria cukup. Maka perlu diadakan pembelajaran pada siklus II dengan melakukan perbaikan-perbaikan langkahlangkah dan tehnik pembelajaran.

Pembelajaran pada siklus II, pelaksanaan tindakan dengan penerapan langkah-langkah pembelajaran metode learning community (belajar kelompok) dengan hasil tindakan pada siklus II adalah dari 37 orang siswa, 26 orang siswa yang meraih nilai 70 keatas atau70,27 \% sedangkan 11 orang siswa masih meraih nilai dibawah 70 (KKM) atau 29,73\%. Hal ini membuktikan adanya peningkatan hasil belajar dari siklus sebelumnya, tapi belum mencapai indikator keberhasilan yaiti $85 \%$ (ketuntasan klasikal) disebabkan karena belum bias menciptakan yang aktif dan Pada siklus II siswa merasa malu untuk bertanya, mengajukan pendapat dan menjawab pertanyaan guru, untuk mengatasi masalah tersebut, pada siklus II guru memotivasi siswa untuk lebih berani mengemukakan pendapatnya, tidak takut salah dan dan jika kesulitan maka siswa jangan malu untuk bertanya, baik kepada teman maupun guru.

Pembelajaran pada siklus III, pelaksanaan tindakan yaitu penerapan langkah-langkah pembelajaran metode learning community (belajar kelompok) dengan mempertahankan langkah-langkah yang telah terlaksana dengan baik dan meningkatkan hal-hal yang kurang sempurna, seperti membimbing siswa secara terus menerus, memberika perhatian pada saat siswa melakukan diskusi kelompok, dan memberikan penjelasan dengan bahasa yang mudah di pahami. Hasil tindakan pada siklus III menunjukan adanya peningkatan yang siknifikat. Peningkatan itu adalah dari 37 orang siswa, 33 orang siswa yang meraih nilai 70 keatas atau $89,20 \%$ sedangkan 6 orang siswa belum atau $13,00 \%$ belum mendapat Indikator keberhasilan individu yang telah ditetapkan.

Kemajuan tersebut sebagai manifestasi dari pelaksanaan metode learning community ( belajar kelompok) bimbingan dari guru, latihan yang terus menerus dengan waktu yang cukup, dan tugas yang menantang dan variatif. Semua itu membantu siswa menjelaskan sistem pemerintahan kabupaten/kota. Dari hasil pengamatan dan diskusi dengan observasi siswa sudah aktif dan atosias dalam belajar karena guru sudah menerapkan metode learning community (belajar kelompok) secara optimal. Penjelasan guru juga menggunakan bahasa yng sudah di mengerti, sehingga tercipta suasana yang bergairah dan siswa senang menerima pelajaran. Dengan penerapan metode learning community (belajar kelompok) dalam pembelajaran PPKn dapat menciptakan suasana yang aktif dan efektif serta menyenangkan, yang berdanpak pada tingkat pemahaman siswa terhadap materi pokok pembelajaran yang lebih baik. Karena dengan penerapan metode learning community (belajar kelompok) yang benar, efektif dalam meningkatkan hasil belajar siswa. Hal ini dapat di lihat dari tes hasil belajar siswa pada siklus III. Dengan demikian upaya meningkatkan hasil belajar pendidikan PKn melalui pembelajaran learning community pada siswa sekolah dasar dapat meningkat secara signifikan. Hasil tersebut sejalan dengan pendapat yang menjelaskan bahwa hubungan antara pembelajaran learning community (belajar kelompok) dengan pendidikan kewarganegaraan saling terkait.[13] Pembelajaran kontekstual dengan pengajaran kelompok akan meningkatkan keterlibatan dan hasil belajar PKn.[14] Pada learning community dapat memberikan hasil baik untuk kemajuan perangkat pembelajaran, dengan adanya dialog dan hubungan antara guru dan guru serta antara guru dan guru telah dikembangkan.[15]

\section{E. SIMPULAN DAN SARAN}

Berdasarkan hasil penelitian menunjukkan bahwa dengan menerapakan pembelajaran learning community dapat meningkatkan hasil belajar siswa sekolah dasar, dengan hasil tindakan pada siklus I ketuntasan belajar $56,76 \%$ dan nilai rata-rata 69,83 , dan pada siklus II mengalami peningkatan tetapi belum memenuhi indikator keberhasilan yaitu ketuntasan belajar 70,27\% dengan nilai rata-rata 84,08 . Sedangkan pada siklus III mengalami peningkatan yang sangat siknifikat yaitu $89,20 \%$ dengan nilai rata-rata 84,08 . Dengan demikian sikus III mengalami peningkatan yang siknifikat dan memenuhi indikator keberhasilan (nilai klasikal) dari siklus sebelumnya.

Diharapkan kepada guru dapat menemukan format baru dalam merancang pembelajaran khususnya pada mata pelajaran PPKn, dengan menggunakan pembelajaran yang berorientasi pada metode learning community (belajar kelompok). Dapat memberikan kontribusi bagi sekolah sebagai salah satu alternative untuk meningkatkan mutu dan kinerja guru melalui peneltian tindakan kelas. Sehingga kualiatas proses dan 
hasil belajar pada mata pelajaran PPKn pada khususnya dan seluruh mata pelajaran pada umumnya.

\section{UCAPAN TERIMA KASIH}

Penulis mengucapkan terima kasih kepada berbagai pihak yang senantiasa memberikan bantuan dana, dan data penelitian sehingga penelitian ini selesai dengan baik.

\section{DAFTAR RUJUKAN}

[1] S. N. Uribe, "Investigating the Benefits of Curriculum-Based Readers Theatre for English Language Learners Through an Innovative Professional Learning Community Model," Wiley Handb. Action Res. Educ., pp. 565-579, 2019.

[2] J. Zhang, "The Construction of College English Online Learning Community under ADDIE Model.," English Lang. Teach., vol. 13, no. 7, pp. 46-51, 2020.

[3] E. S. N. Jannah, "Penerapan Metode Pembelajaran 'Active Learning-Small Group Discussion' di Perguruan Tinggi Sebagai Upaya Peningkatan Proses Pembelajaran," FONDATIA, vol. 3, no. 2, pp. 19-34, 2019.

[4] L. I. Wahyuni, "Penerapan model pembelajaran learning community tema lingkungan pada pembelajaran tematik guna meningkatkan hasil belajar siswa kelas III SDN Mulyoagung Kecamatan Dau Kabupaten Malang," Penerapan Model pembelajaran Learn. community tema Lingkung. pada pembelajaran Temat. guna Meningkat. Has. belajar siswa kelas III SDN Mulyoagung Kec. Dau Kabupaten Malang/Luluk Ika Wahyuni, 2010.

[5] A. Rohyanto, "Penerapan Strategi Learning Community Sebagai Upaya Meningkatkan Keaktifan Belajar IPS Pada Siswa Kelas II SD Negeri 2 Senggrong Kecamatan Andong Kabupaten Boyolali Tahun Pelajaran 2012/2013." Universitas Muhammadiyah Surakarta, 2012.

[6] A. Samsudin, "Supervisi Akademik Pembelajaran IPA Melalui ICT Based Lesson Study Untuk Membangun Learning Community Guru SD,” Mimb. Sekol. Dasar, vol. 1, no. 1, pp. 77-82, 2014.

[7] H. Afriansyah, "Administrasi Pendidikan di Indonesia," 2019.

[8] D. Rusman and M. Pd, "Model-model pembelajaran," Raja Graf. Jakarta, 2012.

[9] B. L. Smith, "Taking Structure Seriously: The Learning Community Model.," Lib. Educ., vol. 77, no. 2, pp. 4248, 1991.

[10] R. DuFour, "What is a' professional learning community’?, Educ. Leadersh., vol. 61, no. 8, pp. 6-11, 2004.

[11] A. S. Rahayu, Pendidikan Pancasila dan Kewarganegaraan (PPKn). Bumi Aksara, 2017.

[12] U.-U. R. Indonesia, "Sistem Pendidikan Nasional," Jakarta Direktorat Pendidik. Menengah Umum, 2003.

[13] R. Rachmadtullah, "Kemampuan berpikir kritis dan konsep diri dengan hasil belajar pendidikan kewarganegaraan siswa kelas V sekolah dasar," $J$. Pendidik. Dasar, vol. 6, no. 2, pp. 287-298, 2015.

[14] H. Taukhid, "Peningkatan Minat dan Hasil Belajar PKN Melalui Pembelajaran Kontekstual Dengan
Teknik Learning Community Pada Siswa Kelas V Di SD Negeri Babadan Semester 2 Tahun Pelajaran 2015/2016," Refleks. Edukatika J. Ilm. Kependidikan, vol. 6, no. 2, 2016.

[15] A. N. Widiadi and I. W. Utami, "Praksis lesson study for learning community dalam pembelajaran ilmu pengetahuan sosial pada sekolah menengah pertama melalui kolaborasi kolegial guru dan dosen,” J. Teor. dan Praksis Pembelajaran IPS, vol. 1, no. 2, pp. 77-88, 2017. 